\title{
MANAGING PEOPLE IN HOSTILE ENVIRONMENTS: LESSONS LEARNED AND NEW GROUNDS IN HR RESEARCH
}

\begin{abstract}
Questions related to managing people in hostile environments have become more central on the agenda of business leaders and HR professionals in MNCs. This is due to developments such as the increase of terrorism or the political instability in many regions. In consequence, research on the role of HR in hostile environments has increased as well, though it can still be considered in its early stages.We would like to review the current state of research on managing people in hostile environment. In particular, with this article we contribute to the literature by developing a conceptual framework that distinguishes between micro, mezzo and marco level research and charts progress, mechanisms and results. We call this the Situation - Response - Outcome (SRO) Framework of HRM in hostile environments. Depending on the level of analysis, the framework further differentiates between a pre-crises, acute-crisis, and post-crises phases of HRM in hostile environments. As a result, it serves as the basis to cluster existing literature around it and to show avenues for future research.
\end{abstract}

Keywords: Terrorism; Hostile Environments; People Management; Situation - Response - Outcomes Framework; Research Agenda 


\section{INTRODUCTION}

With the terrorist attacks in New York and Washington on September 11, 2001 (hereafter 9/11), terrorism was catapulted to the top of governmental agendas around the world. We can certainly say that this event has been a tipping point at least in how terrorism is perceived in the wider society (Woods, Eyck, Kaplowitz, \& Shlapentokh, 2008). But not only governments started to change their perception on terrorism. Terrorism suddenly became highly relevant in the business context as well (Suder, 2004). Terrorist groups seek to destabilize the economy as a whole by attacking business premises or specific companies to advance their political or ideological agendas (Alexander, 2004). Despite a slight drop of terrorism-related incidents between 2001 and 2004, the number of attacks has tremendously grown year by year with a peak of 16,860 incidents in 2014 (Global Terrorism Database, 2017). A significant terrorist threat comes from international terrorism, which generally targets Western businesses and people located outside or inside their home country, with the ambition to mount high impact attacks designed to result in mass casualties in order to receive a broad media attention. Therefore, it is not surprising to see that the number of terrorism-related incidents in OECD countries has also dramatically increased in recent years, largely due to ISIS/ISIL inspired attacks. In fact, according to the Institute for Economics and Peace, we witnessed a 67 percent increase in attacks and a nearly 600 percent increase in deaths from terrorism between 2014 and 2016. A significant portion of the fatalities was caused by a few high-impact attacks. For example, the Paris attacks in November 2015 resulted in 137 deaths; the Nice truck attack in July 2016 caused 87 deaths; and the Orlando nightclub shooting in June 2016 resulted in 50 deaths (Institute for Economics and Peace, 2017).

In the literature on terrorism, there is a consensus that a main goal of the perpetrators of terrorist attacks is to disrupt society by evoking a culture of fear, anxiety and panic. This is achieved by transmuting a specific terrorist incident beyond its localized setting and thereby creating a perception that every resident and company is vulnerable to terrorism (Cronin, 2003; Victoroff, 2005). Repeated and large-scale terrorist attacks targeting the business sector and its employees caused that Multinational Companies (MNCs) from any part of the world are affected, especially if they operate in 
and send employees to high-risk countries where terrorism and other disturbances are a commonplace occurrence. This does not necessarily mean that MNCs face direct consequences of terrorism such as human costs (loss of life, physical injury) or the destruction of buildings and equipment. In fact, only few MNCs experience these direct effects. Instead terrorism's indirect effects tend to be widely felt (Czinkota, Knight, Liesch, \& Steen, 2010). Indirect effects include declines in foreign direct investments, disruptions in the international supply chains of MNCs, new governmental regulations and immigration laws and negative reactions of employees towards their employers (Czinkota, Knight, Liesch, \& Steen, 2005; Frey, Luechinger, \& Stutzer, 2007). In particular, employees that are exposed to terrorism-related threats often suffer from post-traumatic stress, anxiety, feelings of insecurity, decreased self-efficacy, and a decrease in subjectively rated health (Peus, 2011).

However, terrorism is not the only form of violent risk and danger to which MNCs and its employees are exposed. Apart from terrorism, there are other leading causes of violence and instability around the world such as ethnopolitical conflicts, civil unrest, civil war, and drug-related crime, which show tremendous effects on the business activities of MNCs, especially for subsidiaries of foreign MNCs (Oh \& Oetzel, 2011; Ramirez, Madero, \& Muñiz, 2016).

Therefore, it can be considered as a natural response that questions related to managing people in those hostile environments ${ }^{1}$ have nowadays become commonplace on the agenda of business leaders and HR professionals in MNCs (Dickmann, 2017), especially since the expatriate population who is sent to broad set of countries continues to grow (Brookfield Global Relocation Services, 2016). When comparing the agendas of human resource management (HRM) in hostile environments with those in normal settings, we see that HRM is confronted with additional challenges, which do not occur in such intensity in normal settings. This starts with finding employees who are willing to work in hostile environments, executing safety and security policies, providing safety trainings, developing internal intelligence and communication strategies of potential hazards and risks, developing emergency and recovery plans, adapting compensation schemes by adding appropriate hardship allowances, and

\footnotetext{
${ }^{1}$ We define 'hostile environment' as a country, region, or specified location, which is subject to war, terrorism, insurgency, civil unrest, or extreme levels of crime, banditry, lawlessness, or public disorder.
} 
offering post-trauma support when employees are involved in a terrorist incident. Also for individual expatriates who live and work in high-risk countries, those hostile environments cause additional challenges beyond those of a common international assignment as they cannot move freely throughout the country, have to live in closed and secured compounds, often require bodyguards for being chauffeured to their work location, and need to handle an increased vulnerability and stress levels. To better understand the unique setting of hostile environments for managing people, an increasing number of scholars, academics, and specialized business consultants started to address those topics from an HR perspective. In this regard, we contribute to this research by developing a framework that distinguishes between a pre-crises, acute-crisis, and post-crises phases (i.e., has a process perspective). We then cluster existing literature around it and show starting points for future research.

\section{PEOPLE MANAGEMENT IN HOSTILE ENVIRONMENTS: LESSONS LEARNED}

Despite a very early, ground-breaking study of Michael Harvey (1993) and frequent calls for more research with some initial studies on the topic in the first years after 9/11 (e.g., Czinkota, Knight, Liesch, \& Steen, 2005; Howie, 2007), research on managing people in hostile environments still has not made its way into mainstream IHRM literature. In fact, even though we witnessed a significant increase of research on hostile environments in the IHRM literature over the last decade, the research stream is still in its infancy and scattered. We do not intend to present a comprehensive literature review here but rather like to outline the current state of knowledge in the field and systemize previous studies regarding people management in hostile environments. This does not only help us to better understand different streams of research on hostile environments but also enables us to better categorize the articles in this Special Issue and to provide recommendation on how research on hostile environments can break new grounds. As outlined above, Harvey (1993) was among the very first scholars to explore the impact of terrorism on business in general and on HRM in particular. In this seminal study it becomes apparent that research on terrorism simulatoneously takes place on a macro, mezzo, and micro levels. Based on this observation, we create an overarching framework for managing people in hostile environments by distinguishing between three perspectives: macro, mezzo, and micro. 
On the macro level, the role of national governments has played a vital role for managing people in hostile environments. Already in 1993, Harvey pointed out that national governments do not provide adequate assistance when companies were attacked by terrorists. Sandler and Enders (2005), who studied the economic consequences of terrorism in developed and developing countries, showed that governments of developed markets may be better to support the business sector after a terrorist attack. It is outlined that governments in developed markets are better equipped with monetary or fiscal stimuli following terrorist attacks and have more sophisticated defensive measures such as antiterrorism laws, immigration policies, or public security means (law enforcement, intelligence and information services, emergency management) that enable the state to restore confidence in society after terrorist attacks. It is clear that the security apparatus of the state - military, intelligence, and police forces - have a key role in identifying and dealing with terrorist threats and atrocities. Moreover, there is evidence that terrorism can have severe consequences for the business sector by reducing capita income growth (Blomberg, Hess, \& Orphanides, 2004), shrinking GDP, investments and exports (Eckstein \& Tsiddon, 2004), decreasing firms' international competitiveness (Spich \& Grosse, 2005), or lowering bilateral trade when a country that experienced a terrorist incident is a trading partner (Nitsch \& Schumacher, 2004). Another important issue at the macro-level is to differentiate between types of hostile environments (terrorism, crime, civil unrest, etc.) in order to show the unique impact on MNCs and their employees. In this matter, there is already initial evidence in the literature that the feeling of vulnerability and anxiety after terrorist incidents is more pervasive and persistent with greater mental health consequences than effects from other types of hostile environment and disasters (Holloway \& Fullerton, 1994; Jacobs \& Kulkarni, 1999; James, 201 1b; Ryan, West, \& Carr, 2003). In contrast, a recent study by Faeth and Kittler (2017) showed that expatriates in a more terrorism-exposed context perceive fear less strongly than expatriates in environments with high degrees of conventional crime. A reason for this could be that becoming victim in a crime is regarded as more likely than becoming victim in a terrorist attack, even though the consequences may be less severe.

At the mezzo-level, the focus has been on how MNCs and their HR departments can manage people in hostile environments. The topics here have been widely connected to corporate strategies, HR policies, 
and HR practices in the context of hostile environments. The global mobility literature takes a process perspective that distinguishes between pre-assignment, during expatriation and post-repatriation phases (Harris, Brewster and Sparrow, 2003). To analyse HR strategies, policies, and practices for global workers in hostile environments, it seems reasonable to develop a framework to follow a process-related perspective and to distinguish between a pre-crises, acute-crisis, and post-crises phase (Devlin, 2006; Fee, McGrath-Champ, \& Liu, 2013). These three process categories were already underlying the work of Harvey (1993). Concerning the pre-crisis phase he revealed - based on the survey results of 79 US Fortune 500 companies - that more than half of those companies had absolutely no formal programs to deal with the impact of potential terrorist attacks. Those that had a program in place prioritized to spend money on security equipment instead of training executives, expatriates, and accompanying family members. Based on his findings, he recommended that in a precrisis phase, companies need to gather information about potential terrorist threats, provide training to executives and their families, and to form a crisis management team that will be prepared for the possibility of a terrorist attack. More recent research outlines various instruments on how MNCs can increase the safety and security of expatriates in hostile environments. For instance, it is argued that MNCs can better guide expatriates during terrorist-related incidents when they have developed formal HR policies related to employees safety and security and created evacuation plans prior to an actual incident (Devlin, 2006; Fee \& McGrath-Champ, 2017; Sánchez \& Goldberg, 2003).

Moreover, MNCs should gather intelligence on potential hazards and risks by collecting and analyzing information on possible crisis triggers (Kalbassi, 2016). In addition, Fowler, Kling and Larson (2007) investigate whether different organizations vary in their corporate strategies towards organizational preparedness for coping with hostile environments and provide initial evidence that for-profit organizations have a lower organizational preparedness than public organizations. They also conclude that decision-makers in for-profit companies may be less willing to spend money on these types of plans than those in public organizations. Finally, it is argued that MNCs can offer trainings and briefings to increase expatriates' awareness of potential risks and to provide them with instruments on how to reacted when they face a potential crisis (Darby \& Williamson, 2012). 
In the acute-crisis phase, it is of utmost importance to have a crisis management team at hand that ensures the implementation of safety and security plans on site and that guides and supports expatriates during incidents (James, 2011a). A study amongst global mobility professional has shown that many MNCs cooperate with government and private security forces in terms of working on crisis reaction plans and provisions (Dickmann, 2015). It is interesting to note, that some companies seem to treat their expatriates differently from local partners and family. Unfortunately, a large number of MNCs do not have any elaborated crisis reaction approach which indicates that much of the host country risk is borne by assignees themselves. Many authors have observed a substantial increase into the exploration of self-initiated expatriates (Andresen; Al Ariss \& Walter, 2012; Vaiman \& Haslberger, 2013). Little is known about these SIEs living in hostile environments and their reaction to, say, terrorist incidents.

Finally, in the post-crisis phase, MNCs need to support expatriates to deal with psychological trauma and ensure an efficient readjustment of the expatriate in the work and social environment (Hirshon, Eng, Brunkow, \& Hartzell, 1997). In this matter, Waldman, Carmeli and Halevi (2011) revealed that organizations are ineffective in simultaneously responding to both material and psychological needs of individuals in the aftermath of a terrorist event. A second important instrument in the post-crisis phase is that MNCs reflect on the effectiveness of their crisis management and critically evaluate where improvements can be implement (Wang, 2008). Other studies showed how firms respond to major disasters (Oh \& Oetzel, 2011) and violent conflict (Oetzel \& Getz, 2011), revealing that firms reduce the number of their foreign subsidiaries in response to terrorism but not natural disasters.

Up to now, micro-level research has concentrated predominantly on acute and post-crisis analysis. However, there is somegeneral expatriation research that allows some speculation on probably important elements in the pre-crisis phase. Many studies in the general expatriation literature explore the importance of influencing factors on the decision to live and work abroad (Doherty, Dickmann, \& Mills, 2011),which show that the attitudes and personality of expatriates, their career and development plans, financial circumstances, their family situation, general living conditions, and support structures have a strong impact on the decision to work abroad. Where a host environment was seen as insecure and risky, this factor became more prominent and important for the expatriation decision. In addition, 
research indicates that the impression that individuals have about a specific location and the host national's attitudes as well as behaviors shapes their willingness to move there (Dickmann \& Mills, 2009). This is likely to be reflected with respect to hostile environments where there are regions that are more risky compared to other regions in most states that experience hostile and terrorist activities. Regarding the acute and post-crisis phase, most studies have focused on the HR side of terrorism and investigated attitudes and behavior of expatriates in hostile environments. For instance, previous research showed that employees respond to terrorism with lower work motivation and involvement (Bader \& Berg, 2013; Reade, 2009), lack of concentration at work (Mainiero \& Gibson, 2003), higher absenteeism (Byron \& Peterson, 2002), worse work attitudes (Bader, 2015), and lower job satisfaction or commitment (Reade \& Lee, 2012; Vinokur, Pierce, Lewandowski-Romps, Hobfoll, \& Galea, 2011). New scales, for instance to measure sensitivity to terrorism, were introduced (Reade, 2009), fear and coping strategies were studied (Beutell, O'Hare, Schneer, \& Alstete, 2017), and also the role of the expatriates' families was analyzed (Bader, Berg, \& Holtbrügge, 2015). Research showed that terrorism negatively affects expatriates' organizational networking (Kastenmüller et al., 2011) and that working in a hostile environment per se does not decline expatriates' psychological well-being, yet it amplifies the impact of social network characteristics (Bader \& Schuster, 2015). Just recently, Pinto et al. (2017) compiled a Special Issue that exclusively focuses on risky international assignments, presenting new insights into those topics.

We have argued that research on managing people in hostile environments can be done on three different levels. Above, we have outlined a range of relevant factors on the macro, mezzo and micro levels and we have depicted some of the mechanism and outcomes for expatriates (and their families) living in hostile environments in Figure 1. It can be readily seen how a government's approach to dealing with a hostile environment may engage mechanisms such as (anti-terrorism) laws and (immigration) regulations which in turn impacts economic outcomes and the reputation and confidence of citizens and foreigners in the country. On the mezzo level it is reasonable to argue that organizational and HR strategies, policies, and practices will be reflected in security trainings, efforts to prepare organizations and crisis reaction approaches. These will have a range of outcomes linked to the attractiveness to go into high risk locations or pre-mature assignment return in case of hostile acts. 
Lastly, on the micro-level there are a range of factors that determine the willingness to go to hostile environments and the ability to successfully cope with the hardship this often involves. Our framework outlines a variety of personal drivers and personality factors that are reflected in the sensitivity of individuals to terrorism and other hostile acts, their coping strategies and activities while they are embedded in their own host-country social networks. We call this the Situation - Response Outcome (SRO) Framework of HRM in Hostile Environments.

-- please insert Figure 1 about here --

With this Special Issue and our introductory article, we hope to make an important step to further establishing research related to people management in hostile environments in the IHRM literature. By contributing to the current knowledge on this topic, we hope that it will foster even more research in the future. When we first discussed proposing this Special Issue during the 2014 Annual Meeting of the Academy of Management in Philadelphia, we were already looking back at a tremendous increase of terrorist attacks worldwide. At that time, we realized that, given the practical relevance of the topic, there is a dire need for more research on managing people in hostile environments and we were projecting that terrorism and violent conflict will increase in magnitude and, therefore, affect more and more businesses. In response to our Call for Papers (Bader, Schuster, \& Dickmann, 2015), we received a great number of manuscripts, of which twelve were sent out to external reviewers. Overall, these manuscripts covered a variety of research questions on the micro-, mezzo-, and macro-level and we welcomed the diversity and the quality of the studies. After almost two years of revisions and improvements of the manuscripts done by the authors, we are happy to include seven of them in this Special Issue. They all make a great contribution to this small, yet emerging field of research and we are convinced that besides their individual contribution, they are also a great starting point for further research on this important topic. On a personal note, when we first received a submission lead by Michael Harvey, we were very excited, since he can be considered the forerunner of terrorism research in the business context. During the revisions there was a very interesting E-mail conversation on where the field may be moving, that was suddenly stopped by the sad news that Mike had passed away 
in July 2016. It has been an honor to exchange thoughts with him and to be able to include his last article, which has been further revised and finalized by his co-authors, in our Special Issue.

Topics in the articles of the Special Issue range from exploring expatriate safety and security practices (Fee, Mcgrath-Champ, \& Berti, 2018), withdrawal cognitions (A. K. Bader, Reade, \& Froese, 2018), to employee protection (Gannon \& Paraskevas, 2018) or staff localization (Dickmann, Parry, \& Keshavjee, 2018). Other articles focused on the role of knowledge (Suder, Reade, Riviere, \& Birnik, 2018) and adjustment, psychological contracts, and risk management (Posthuma, Ramsey, Flores, Maertz, \& Ahmed, 2018) in hostile environments. Finally, Harvey et al. (2018) propose a terrorism preparedness plan for companies, pointing out the employer's Duty of Care. Overall, we believe they are a great mix of different approaches (methodologically and theoretically) to answer questions in this important research field.

Our Special Issues opens with Harvey et al. (2018), whose study is located at the mezzo-level. In this study, the authors look at the increasing impact of global terrorism on multinational organizations and its significance for strategic global human resource management. They claim that it is the responsibility of corporations doing business in hostile environments to protect their human capital from external terrorism by being proactive about its effects and specifically outline that this is a part of the employer's Duty of Care. In addition, they discuss the need to keep international assignees safe as working outside one's home country is an exceptional challenge that could worsen by disaster-related situations that might occur from the effects of terrorism. The article provides an overview about the current literature dealing with terrorism's effects on business as well as a 'terrorism preparedness plan' that aims to inform international assignees about 'what if' situations in a country before moving there. Its major contribution can be seen in the fact that it enables assignees to handle possible threats of terrorism in a better way and that it helps companies to decrease a possible lack of legitimacy, which in turn prevent companies to face a reduced talent pool.

The second article, authored by Fee et al. (2018), looks at managing people in hostile environments from both a macro-level and a mezzo-level perspective by investigating institutional forces that can impact the security and safety of international organizations operating in a hostile location, e.g. countries with a difficult political situation, terrorism, or natural disasters. The study provides an 
insight into the security practices of 28 global companies from three industries that operate in such locations. Drawing on institutional theory, Fee et al. (2018) classify the observed security practices into three approaches: 'regulatory,' 'informal mentoring,' and 'empowering'. By identifying betweenand within-sector patterns of safety and security practices that are shaped by institutional pressures, the authors develop a platform for initial theory building in relation to the elements of organizations' safety and security practices which are influenced by institutional factors. In addition, the authors reveal that there is more than one institutional force driving a company's operations in foreign countries, as the analyzed practices were shaped by the home country and the organization's internal culture as well as the relationship to the host country and the specific industry they are operating in. Overall, this study provides answers on how the HR practices are influenced by different institutional forces and what options a company has for supporting expatriate safety and security in hostile locations - thus contributing to a better comprehension of HR choices in these locations. The third article, authored by Gannon and Paraskevas (2018), is located at the mezzo-level and examines best practices for preparing and protecting employees of multinational organizations in hostile environments. By conducting interviews with corporate executives, insurers, and relocation specialists who have a strong professional expertise on the topic, the authors deliver insight into the development and utilization of support and protection practices as well as the risks to which managers are exposed in hostile locations. Choosing the international hotel industry and its role in high-risk countries as the setting for the study, the results highlight the challenges that internationally active organizations face when protecting their expatriates and emphasizes the importance of expertise from specialists and management dealing with risk, security, and insurance. Accounting for the managers' point of view, the article focuses on an investigation of organizational challenges rather than the challenges that might occur for individuals. At the end, the authors offer a set of meaningful propositions for human resource management in hostile locations by systematically considering ethical and strategic challenges that might arise in a multinational company.

The fourth study evolves around the issue of withdrawal cognitions of expatriates in terrorismendangered countries (A. K. Bader et al., 2018) and is consequently located at the micro-level. The study builds on stress theory and takes influences of perceived threats and constraints into account. 
More precisely, the authors differentiate between the perception of work (related to the new job requirements in the host country and thus the work domain), interaction (related to social interactions with host country nationals in the work and non-work domains), and general constraints (related to the general living conditions particularly in the non-work domain). They therefore make a contribution to the literature on expatriates in terrorism-endangered countries by specifically linking terrorism to stressors that influence withdrawal cognitions. Empirical results from a survey among 160 expatriates working in hostile environments show a relation between the level of terrorism and the perceived threat, furthermore identifying a much stronger effect of this perceived threat in the non-work constraints. While work-related constraints have a direct effect on job turnover intentions, non-work constraints have a direct effect on country leave intentions. By also looking at spillover effects from the non-work to the work domain, the authors could further identify an indirect effect from perceived non-work constraints to job turnover intentions through intentions to leave the country. Based on these results, the study develops suggestions on how multinational organizations can best support their employees in the expatriation process.

This is followed by a qualitative study by Suder et al. (2018), which is once again located at the mezzo-level. The study looks into the human resource management of a European telecommunications joint venture in Afghanistan. It especially highlights the managerial learning and knowledge acquisition in hostile and often unknown environments by investigating how knowledge gaps can be addressed and how rare knowledge can be captured and leveraged by HR practices. This is important as organizations operating in developed countries often need to adapt to dangerous and 'extreme' contexts and moreover fill institutional voids by creating supplies that would usually be offered by the government. Their study examines how the telecommunications company is dealing with the issue of learning in a hostile environment while also trying to leverage the acquired knowledge to other hostile locations. The authors state that human resource management as well as the willingness of the expatriate to learn and share knowledge play a critical role in the knowledge acquisition process, because assignees can act as knowledge carriers between the head office and the subsidiary. Specialized consultants can further support the learning process. It is proposed that by using the right HR practices to support the acquisition of rare knowledge in hostile locations, organizational learning 
will be enhanced, hence creating competitive advantages for internationally operating corporations and benefiting such organizations in their operations. On top of that, the study includes theory development in terms of a mechanism for capturing and leveraging the rare knowledge gained in one extreme location to other hostile environments, based on experiential learning used by the military. The findings contribute to the international human resource management, organizational learning, and international business literatures by offering implications for both international human resource management and building organizational resilience through acquisition and exploitation of knowledge. In the sixth article, Posthuma et al. (2018) offer a model of guidance for management practices to reduce environmental stress and its negative effects on expatriate adjustment. As a result, the article combines a mezzo-level and a micro-level perspective. The authors state that as expatriates move to hostile locations because of their work, there is a perceived need for the employer to not only fulfill core work related obligations but to also get proactive in non-work issues. The authors argue that the psychological contract between the employer and the employee working in a hostile environment needs to be expanded by protecting expatriates from the direct and indirect effects of the risks they are exposed to. The developed risk management framework is based on the idea of a psychological contract and proposes ways how HRM practices can contribute to expatriates' adjustment. Its foundation is built upon literature streams on expatriate adjustment, psychological contract, and risk management. In particular, the article examines the effect of expatriate adjustment on role performance, proposing expatriate psychological resilience as a moderator. Posthuma et al. (2018) conclude with a discussion about the role of expatriate risk management by the organization. They argue that the approach of psychological contracts to understand the negative effects of hostile environment can lead to the reduction of environment-related stress on the individual level. Finally, the last article in this Special Issue is an exploratory investigation located at the mezzo-level by Dickmann et al. (2018), dealing with the localization of staff in Afghanistan. Localization is considered important to manage risks and gain resources needed for competitive advantage. Dickmann et al. (2018) expand the existing literature by illustrating a set of relevant drivers and constraints that influence the decision to localize staff in hostile environments. It further explores resource-based and institutional influences, using the resource-based view and institutional theory as a theoretical 
background. Their goal is to help multinational companies to make better decisions in localizing professional staff in hostile environments. Notably, the article offers a practical guide to assist companies thinking about localizing staff in Afghanistan or similar hostile environments. The results identify new influences on localization, like ongoing security issues, corruption, impartiality, and the need for outside experiences among others. The authors additionally emphasize the importance of not just picking appropriate local human resources but also using the right internal capabilities to develop and deploy them for a sustainable competitive advantage and therefore connect theory and practical usability.

\section{PEOPLE MANAGEMENT IN HOSTILE ENVIRONMENTS: NEW GROUNDS}

While the articles enrich our thinking and understanding on managing people in hostile environments, they also raise new questions and show avenues for future research. As argued above, given its increased practical relevance for MNCs, we are only at the beginning and believe that this important stream of research will further make its way into mainstream literature. To break new grounds, we apply the newly developed SRO Framework of HRM in Hostile Environments and outline several research avenues that have the potential to strongly contribute to our current understanding in the filed of managing people in hostile environments. ${ }^{2}$

On the macro-level, research needs to better tie the relevant factors to the outcomes. For instance, how does the type of hostile environment actually affect economic growth and the creation of jobs? What can the government do in order to (re)build confidence in society? And, maybe in a more fundamental way, what is the "economic cost" of terrorism for business in a given country? In addition, a more nuanced understanding of hostile environment may be highly useful. Distinguishing between humaninduced terrorism or natural disasters will have an impact on state, organizational and individual

\footnotetext{
${ }^{2}$ When working on this part of the introductory article, we felt that some of the best experts are, in fact the authors contributing to this Special Issue. Thus, besides summarizing what they wrote in their respective articles, we approached them via E-mail and asked them to share their thoughts with us. We gladly incorporated their valuable feedback when drafting the section on new grounds in research on people management in hostile environments.
} 
activities and concerns. Developing a classification of degrees of different hostility in certain countries or specific intra-country locations would advance our knowledge. In fact, previous research often relies on either sensitivity and perception of terrorism risk by individuals, external data on country level, such as from the Global Terrorism data base, or a combination of both. However, neither approach is superior per se. For instance, relying on the perception by individuals may be adequate when the outcome variables are exclusively on individual level. However, using individual perceptions may cause potential issues of common method variance (CMV) when all data are obtained by a single informant. Using external data may overcome problems with CMV, yet if it does not account for the very specific location, it may be flawed. In many countries that suffer from terrorism, there are certain regions that are severely affected, while others are much better off. Using a country-average may cause the problemthat it over- or underestimates the true threat level. Macro-level research can add great value in explaining the context of mezzo- and micro-level research. It sets the scene and we know very little about the respective influence macro-level factors have on people management in hostile environments.

On the mezzo-level, we need to extend our knowledge on HR policies and practices. In other words, what are companies doing in order to protect their staff abroad, what is their role in terms of Duty of Care, and how does this shape the companies' strategies? We have argued above that intra-country location has a bearing on whether individuals want to go to a specific city or rural area (Dickmann, 2013). Internationally operating organizations often have a good feeling for the relative attractiveness of their diverse locations and could start to 'manage' the foreign experiences and associated (including monetary) outcomes that assignees experience. We know that going to hardship locations within a UN organization was associated with different career outcomes than going to non-hardship duty stations (Dickman \& Cerdin, 2016). Much more research is needed to understand the range of company activities to attract and manage assignees and their families going to hostile environments and to explore individual and organizational outcomes.

Following our call among the authors of the articles in this Special Issue, one of them raised the question of how to deal with increased real and perceived inequality between expatriates and the local population in various countries. They shared a story of an incident, where an expatriate got violently 
robbed on their way to the airport while getting stuck in traffic and under the (correct) assumption of the assailant that the person in the car is (relatively) rich. It is quite common for expatriates at a certain hierarchical level to have a chauffeur and be driven around in the back seat of a nice car. Had the company adviced to travel "low profile", for instance using a regular taxi or inconspicuous car, the risk level would have been different. Yet, by showcasing their status, the company presented an opportunity for the attacker. The robbery could also have resulted in kidnapping. In this case, the expatriate was not harmed physically but suffered from this traumatic event by having developed a travel anxiety and not being able to continue the assignment. Hence, future research should dig much deeper in corporate HR practices in hostile environments, investigating unconventional tatics and practices and their efficiency in order to protect their staff abroad and find the right balance between pleasing their expatriates with amenities and at the same time increasing their safety. Especially in poor countries, the income of expatriates allows them to have a lifestyle that is well beyond the typical lifestyle in the host country. This inequality awakens desires among elements of the local population and, consequentially, might cause some individuals to take criminal action.

Another interesting avenue for mezzo-level research is managing perceived fear of individuals. Basically, fear on the individual level may aggregate up to the team, subsidiary, and firm level. Media reports and contagion effects in social networks (Bader \& Schuster, 2015) may even fuel this fountain effect. However, research has yet to answer what mechanisms are underlying this multi-level aggregation and which theories can be applied to understand the effects of higher level HRM practices on lower level relationships and vice versa.

On the interface between mezzo (HR policies) and micro-level, the role of expatriates' families regarding assignments in hostile environments needs more research. Despite a first approach by Bader, Berg, and Holtbrügge (2015), given the long-acknowledged importance of the expatriate's family (Caligiuri, Hyland, \& Joshi, 1998), we know very little about the consequences of making the choice between leaving the family in the home country and opt for a temporal separation and bringing the family along and also expose them to danger. This is pretty much a choice to be between a rock and a hard place. However, with regard to our initial definition of "hostile environments" and the increasing 
number of assignments in all regions of this world, questions regarding the families of expatriates in hostile environments increase in relevance as well.

Finally, even though a big part of research on managing people in hostile environments is actually dealing with the micro-level, we are still far from understanding the whole phenomenon. Again, taking a process perspective might be useful. For instance regarding pre-crisis exposure, it might be fruitful to explore the reasons to go to hostile environments in depth. Findings on the reasons would not only be useful for individual, but also for organizations and even government actors. Indeed, a more profound understanding of the social and host country (support) networks is likely to be important for potential expatriates and for those global mobility professionals who look to increase the attractiveness of their locations in hostile environments. During assignees' stay in hostile locations it would be intriguing to explore their personal risk management strategies and gain more insights into their (in their families') coping with the increased insecurity and stress. This might be enlightening especially with a view to a more nuanced understanding of degrees and forms of hostility. In addition, a better understanding of what working under hardship may mean for the career journey of individuals and their organization's career, knowledge and talent management approaches could give valuable insights to global talent management professionals and career scholars. In terms of understanding post-crisis effects, further studies exploring family effects and long term influences on children and partners would be welcome. There are some indications that some organizations have a substantial percentage of staff who have a preference to go from one hardship location to another (Dickmann \& Cerdin, 2016; Dickmann \& Watson, 2017). It might be possible to learn from their attitudes and coping behaviours so as to prepare those individuals who are embarking for their first sojourn into a hostile environment. In addition, we would welcome research that explores the potential positive effects of working in a high risk context as this may increase the self-esteem or the self-efficacy of individuals. Overall, the field of working in hostile environments is only at its beginning and there are a wide array of future possible research avenues to pursue.

In addition, we would like to argue that one of the next steps needs to be more rigorous study designs, on all levels of analysis, macro, mezzo, and micro. Despite the value and the understandable concerns and hesitations of respondents regarding collection of longitudinal data collection, we need to 
overcome cross-sectional designs in order to understand the dynamic processes of managing people in hostile environments. Collecting data from a single informant at multiple points in time, as well as adding additional data sources in a study to overcome issues related to common method variance (Podsakoff, MacKenzie, Lee, \& Podsakoff, 2003) is necessary to base research questions and respective hypothesis testing on a solid empirical fundament.

While these are mere methodological issues, there is need for future research from a theoretical point of view as well. To begin with, despite the notion that working in hostile environments potentially has negative consequences for expatriates, we need to better understand how these negative consequences can be mitigated. For instance, coping strategies might be a useful mechanism to deal with stress. However, which coping strategies in particular should be applied in a certain situation and how successful one may be over another, is still unclear. Regarding the post-assignment phase, research needs to focus on repatriation from hostile environments. While repatriation is a difficult issue in general and the success widely varies (Breitenmoser \& Bader, 2016, Breitenmoser, Bader, \& Berg, 2018; Doherty \& Dickmann, 2012), it is reasonable to assume that repatriating from a hostile environment comes along with additional challenges. Repatriate research has mainly concentrated on immediate and short-term outcomes, such as job satisfaction, employee turnover, and psychological well-being (Knocke \& Schuster, 2017). However, having experienced potentially traumatizing events may cause long-term effects that occur only years after repatriation. Thus, it would be worthwhile to follow up on this and investigate if former expatriates in hostile environments do experience forms of posttraumatic stress disorder or how such experience affects their lifestyle in general.

\section{CONCLUSION}

The content of this Special Issue clearly reflects the growing research attention for managing people in hostile environments. We therefore reviewed the literature with regard to lessons learned already and developed the SRO Framework identifying relevant elements of research on people management in hostile environments. After having introduced the articles included in this Special Issue, we proposed new grounds for future research, again clustered along our framework. By doing so, we aim to contribute to further setting and refining the research agenda in this important and emerging field. 


\section{REFERENCES}

Andresen, M., Al Ariss, A., \& Walther, M. (2012). Self-initiated expatriation: Individual, organizational, and national perspectives. London: Routledge.

Alexander, D. C. (2004). Business Confronts Terrorism: Risks and Responses. Madison, WI: The University of Wisconsin Press.

Bader, A. K., Reade, C., \& Froese, F. J. (2018). Terrorism and expatriate withdrawal cognitions: the differential role of perceived work and non-work constraints. International Journal of Human Resource Management, (Part of Special Issue).

Bader, B. (2015). The Power of Support in High-risk Countries: Compensation and Social Support as Antecedents of Expatriate Work Attitudes. International Journal of Human Resource Management, 26(13), 1712-1736.

Bader, B., \& Berg, N. (2013). An empirical investigation of terrorism-induced stress on expatriate attitudes and performance. Journal of International Management, 19(2), 163-175.

Bader, B., \& Berg, N. (2014). The Influence of Terrorism on Expatriate Performance: a Conceptual Approach. International Journal of Human Resource Management, 25(3-4), 539-557.

Bader, B., Berg, N., \& Holtbrügge, D. (2015). Expatriate performance in terrorism-endangered countries: The role of family and organizational support. International Business Review, 24(5), 849-860.

Bader, B., \& Schuster, T. (2015). Expatriate Social Networks in Terrorism-Endangered Countries: An Empirical Analysis in Afghanistan, India, Pakistan, and Saudi Arabia. Journal of International Management.

Bader, B., Schuster, T., \& Dickmann, M. (2015). Call for Papers - Danger and risk as challenges for HRM: how to manage people in hostile environments. International Journal of Human Resource Management, 26(11), 1517-1519.

Beutell, N. J., O'Hare, M. M., Schneer, J. A., \& Alstete, J. W. (2017). Coping with fear of and exposure to terrorism among expatriates. International Journal of Environmental Research and Public Health, 14(7).

Blomberg, S. B., Hess, G. D., \& Orphanides, A. (2004). The macroeconomic consequences of terrorism. Journal of Monetary Economics, 51(5), 1007-1032.

Breitenmoser, A., \& Bader, B. (2016). Repatriation outcomes affecting corporate ROI: a critical review and future agenda. Management Review Quarterly, 66(3), 195-234.

Breitenmoser, A., Bader, B., \& Berg, N. (2018). Why does repatriate career success vary? An empirical investigation from both traditional and protean career perspectives. Human Resource Management, 57(5), 1049-1063.

Brookfield Global Relocation Services. (2016). Global Relocation Trends 2016 Survey Report. Woodridge, IL.

Byron, K., \& Peterson, S. (2002). The impact of a large-scale traumatic event on individual and organizational outcomes: Exploring employee and company reactions to September 11, 2001. Journal of Organizational Behavior, 23(8), 895-910.

Caligiuri, P. M., Hyland, M. M., \& Joshi, A. (1998). Families in Global Assignments: Applying Work 
Family Theories Abroad. In M. A. Rahim \& R. T. Golembiewski (Eds.), Current Topics in Management (Vol. 3, pp. 313-328). Greenwich, CT: JAI Press.

Cronin, A. K. (2003). Behind the curve: Globalization and international terrorism. International Security, 27(3), 30-58.

Czinkota, M. R., Knight, G. A., Liesch, P. W., \& Steen, J. (2005). Positioning terrorism in management and marketing: Research propositions. Journal of International Management, $11(4), 581-604$.

Czinkota, M. R., Knight, G., Liesch, P. W., \& Steen, J. (2010). Terrorism and international business: A research agenda. Journal of International Business Studies, 41(5), 826-843.

Darby, R., \& Williamson, C. (2012). Challenges to international human resource management: the management of employee risk in the humanitarian aid and security sectors. International Journal of Human Resources Development and Management, 12(3), 159-186.

Devlin, E. S. (2006). Crisis management planning and execution. Auerbach Publications.

Dickmann, M. (2017). The RES Forum Annual Report 2017: The New Normal of Global Mobility. London.

Dickmann, M. (2015). The RES Forum Annual Report: Global Mobility and the Global Talent Management Conundrum, RES Forum, UniGroup Relocation Network and Equus Software, 108 pages, London.

Dickmann, M. (2013). "Why do they come to London? Exploring the Motivations of Expatriates to Work in the British Capital", Journal of Management Development, Vol 31(8): 783-800.

Dickmann, M. and Cerdin, J.-L. (2016). Exploring the Development and Transfer of Career Capital in an International Governmental Organization, The International Journal of Human Resource Management, Vol 27: 1-31.

Dickmann, M. and Mills, T. (2009). "The Importance of Intelligent Career and Location Considerations: Exploring the Decision to Go to London", Personnel Review. Vol. 39 (1): 116-134.

Dickmann, M., Parry, E., \& Keshavjee, N. (2018). Localization of staff in a hostile context: an exploratory investigation in Afghanistan. International Journal of Human Resource Management, (Part of Special Issue).

Dickmann, M., \& Watson, A. H. (2017). “I might be shot at!" Exploring the drivers to work in hostile environments using an intelligent careers perspective. Journal of Global Mobility: The Home of Expatriate Management Research, 5(4), 348-373.

Doherty, N. and Dickmann, M. (2012). Measuring the return on investment in international assignments: an action research approach. The International Journal of Human Resource Management, Vol 23(16): 3434-3454.

Doherty, N., Dickmann, M. and Mills, T. (2011). "Exploring the Motives of Company-Backed and Self-Initiated Expatriates", The International Journal of Human Resource Management, Vol 22(3): 595-611

Eckstein, Z., \& Tsiddon, D. (2004). Macroeconomic consequences of terror: theory and the case of Israel. Journal of Monetary Economics, 51(5), 971-1002.

Fee, A., \& McGrath-Champ, S. (2017). The role of human resources in protecting expatriates: Insights 
from the international aid and development sector. The International Journal of Human Resource Management, 28(14), 1960-1985.

Fee, A., Mcgrath-Champ, S., \& Berti, M. (2018). Protecting expatriates in hostile environments: institutional forces influencing the safety and security practices of internationally active organisations. International Journal of Human Resource Management, (Part of Special Issue).

Fee, A., McGrath-Champ, S., \& Liu, H. (2013). Human resources and expatriate evacuation: A conceptual model. Journal of Global Mobility, 1(3), 246-263.

Fowler, K. L., Kling, N. D., \& Larson, M. D. (2007). Organizational preparedness for coping with a major crisis or disaster. Business \& Society, 46(1), 88-103.

Frey, B. S., Luechinger, S., \& Stutzer, A. (2007). Calculating tragedy: Assessing the costs of terrorism. Journal of Economic Surveys, 21(1), 1-24.

Gannon, J., \& Paraskevas, A. (2018). In the line of fire: managing expatriates in hostile environments. International Journal of Human Resource Management, (Part of Special Issue).

Global Terrorism Database. (2017). National Consortium for the Study of Terrorism and Responses to Terrorism (START).

Harris, H., Brewster, C. and Sparrow, P. (2003). International Human Resource Management, London: CIPD Publishing.

Harvey, M. G. (1993). A Survey of Corporate Programs for Managing Terrorist Threats. Journal of International Business Studies, 24(3), 465-478.

Harvey, M. G., Dabic, M., Kiessling, T., Maley, J., \& Moeller, M. (2018). Engaging in duty of care: towards a terrorism preparedness plan. International Journal of Human Resource Management, (Part of Special Issue).

Hirshon, J. M., Eng, T. R., Brunkow, K. A., \& Hartzell, N. (1997). Psychological and readjustment problems associated with emergency evacuation of Peace Corps volunteers. Journal of Travel Medicine, 4(3), 128-131.

Holloway, H. C., \& Fullerton, C. S. (1994). The psychology of terror and its aftermath. Individual and Community Responses to Trauma and Disaster: The Structure of Human Chaos, 31-45.

Howie, L. (2007). The terrorism threat and managing workplaces. Disaster Prevention and Management, 16(1), 70-78.

Institute for Economics and Peace. (2017). Global Terrorism Index 2017. Retrieved from http://visionofhumanity.org/app/uploads/2017/11/Global-Terrorism-Index-2017.pdf

Jacobs, G. A., \& Kulkarni, N. (1999). Mental health responses to terrorism. Psychiatric Annals, 29(6), 376-380.

James, K. (2011a). Introduction to the special issue: Terrorism, disaster, and organizational science. Journal of Organizational Behavior, 32(7), 933-937. https://doi.org/10.1002/job

James, K. (2011b). The organizational science of disaster/terrorism prevention and response: Theorybuilding toward the future of the field. Journal of Organizational Behavior, 32(7), 1013-1032. https://doi.org/10.1002/job

Kalbassi, C. (2016). Identifying Crisis Threats: A Partial Synthesis of the Literature on Crisis Threat Assessment with Relevance to Public Administrations. Journal of Risk Analysis and Crisis Response, 6(3), 110-121. 
Kastenmüller, A., Greitemeyer, T., Aydin, N., Tattersall, A. J., Peus, C., Bussmann, P., ... Fischer, P. (2011). Terrorism threat and networking: Evidence that terrorism salience decreases occupational networking. Journal of Organizational Behavior, 32(7), 961-977.

Knocke, J., \& Schuster, T. (2017). Repatriation of international assignees: Where are we and where do we go from here? A systematic literature review. Journal of Global Mobility, 5(3), 275-303.

Mainiero, L. A., \& Gibson, D. E. (2003). Managing employee trauma: Dealing with the emotional fallout from 9-11. Academy of Management Perspectives, 17(3), 130-143.

Nitsch, V., \& Schumacher, D. (2004). Terrorism and international trade: an empirical investigation. European Journal of Political Economy, 20(2), 423-433.

Oetzel, J., \& Getz, K. (2011). Why and how might firms respond strategically to violent conflict? Journal of International Business Studies, 43(2), 166-186. https://doi.org/10.1057/jibs.2011.50

Oh, C. H., \& Oetzel, J. (2011). Multinationals' response to major disasters: How does subsidiary investment vary in response to the type of disaster and the quality of country governance? Strategic Management Journal, 32(6), 658-681.

Pinto, L. H. F., Bader, B., \& Schuster, T. (2017). Dangerous settings and risky international assignments. Journal of Global Mobility: The Home of Expatriate Management Research, 5(4), $342-347$.

Podsakoff, P. M., MacKenzie, S. B., Lee, J.-Y., \& Podsakoff, N. P. (2003). Common Method Biases in Behavioral Research: A Critical Review of the Literature and Recommended Remedies. Journal of Applied Psychology, 88(5), 879-903.

Posthuma, R. A., Ramsey, J. R., Flores, G. L., Maertz, C., \& Ahmed, R. O. (2018). A risk management model for research on expatriates in hostile work environments. International Journal of Human Resource Management, (Part of Special Issue).

Ramirez, J., Madero, S., \& Muñiz, C. (2016). The impact of narcoterrorism on HRM systems. The International Journal of Human Resource Management, 27(19), 2202-2232.

Reade, C. (2009). Human resource management implications of terrorist threats to firms in the supply chain. International Journal of Physical Distribution \& Logistics Management, 39(6), 469-485.

Reade, C., \& Lee, H.-J. (2012). Organizational Commitment in Time of War: Assessing the Impact and Attenuation of Employee Sensitivity to Ethnopolitical Conflict. Journal of International Management, 18(1), 85-101. https://doi.org/10.1016/j.intman.2011.09.002

Ryan, A. M., West, B. J., \& Carr, J. Z. (2003). Effects of the Terrorist Attacks of 9/11/01 on Employee Attitudes. Journal of Applied Psychology, 88(4), 647-659. https://doi.org/10.1037/00219010.88.4.647

Sánchez, C., \& Goldberg, S. R. (2003). How to handle the threat of catastrophe. Journal of Corporate Accounting \& Finance, 14(6), 35-40.

Sandler, T., \& Enders, W. (2005). Economic Consequences of Terrorism in Developed and Developing Countries. In P. Keefer \& N. Loayza (Eds.), Terrorism, Economic Development, and Political Openness (pp. 17-47). Cambridge, MA: Cambridge University Press.

Spich, R., \& Grosse, R. (2005). How does homeland security affect U.S. firms' international competitiveness? Journal of International Management, 11(4), 457-478.

Suder, G. S. (2004). Terrorism and the International Business Environment: The Security-Business Nexus. (G. S. Suder, Ed.). Northampton, MA: Edward Elgar Publishing Ltd. 
Suder, G. S., Reade, C., Riviere, M., \& Birnik, A. (2018). Mind the gap: the role of HRM in creating, capturing and leveraging rare knowledge in hostile environments. International Journal of Human Resource Management, (Part of Special Issue).

Vaiman, V., \& Haslberger, A. (2013). Talent management of self-initiated expatriates: A neglected source of global talent. Hamburg: Springer.

Victoroff, J. (2005). The mind of the terrorist: A review and critique of psychological approaches. Journal of Conflict Resolution, 49(1), 3-42.

Vinokur, A. D., Pierce, P. F., Lewandowski-Romps, L., Hobfoll, S. E., \& Galea, S. (2011). Effects of war exposure on air force personnel's mental health, job burnout and other organizational related outcomes. Journal of Occupational Health Psychology, 16(1), 3.

Waldman, D. A., Carmeli, A., \& Halevi, M. Y. (2011). Beyond the red tape: How victims of terrorism perceive and react to organizational responses to their suffering. Journal of Organizational Behavior, 32(7), 938-954.

Wang, J. (2008). Developing organizational learning capacity in crisis management. Advances in Developing Human Resources, 10(3), 425-445.

Woods, J., Eyck, T. A. Ten, Kaplowitz, S. A., \& Shlapentokh, V. (2008). Terrorism risk perceptions and proximity to primary terrorist targets: how close is too close? Human Ecology Review, 15(1), $63-70$. 